\title{
Europe's Armed Forces in Civil Security
}

\author{
John L. Clarke *
}

\section{Introduction}

Two decades after the end of the Cold War, does Europe need armies? What should soldiers do, besides fighting and preparing to fight? What tasks are (and are not) appropriate for soldiers to carry out in a domestic context? Is territorial defense still a valid mission for European armed forces? And are there better-and cheaper-solutions?

These questions have become increasingly difficult to answer in the current strategic and budgetary environment. Armies are expensive, and the threat environment for most European countries has evolved significantly over the past two decades. As a consequence, taxpayers may look askance at defense expenditures, wondering why it is still necessary to pay so much for a capability that no longer seems necessary and might even be redundant. Those defense expenditures also represent tempting targets for politicians anxious to cut budgets in times of austerity.

This study is intended to help examine these issues, with a view towards trying to provide answers to the questions of what armies (and, by extension, navies and air forces) can do, should do, must do - and, equally important, should not do - particularly in a domestic context. With the tremendous pressures on governments to save money, these questions are likely to become even more salient in the near future.

For armies are convenient targets, and relatively easy to cut. In most European countries, defense expenditures are discretionary, unlike entitlement programs. Their constituencies - though often powerful, particularly in the defense industry - are small, and military forces, particularly contemporary professionalized forces, lack significant popular support. Absent a sense of external threat, militaries are often unappreciated. These professional armies, as is the case in most European countries, are generally small and have little lobbying power and few friends in high places. They are vulnerable. But they are also available, for what often seems to be whatever task comes up.

Thus, "Let the army do it" is a phrase often heard in many countries when a tasksuch as the recovery from an earthquake-exceeds the abilities of local and regional, and often even national, authorities. Military forces are often seen, justifiably or not, as sitting in their bases, waiting for something to do. And since engaging the military in a civil security task is often viewed as free of both cost and risk, the temptation on the part of political leaders to "let the army do it" is great indeed. And it must be said that, for many tasks, it is appropriate to "let the army do it" - but not for all tasks at all times.

This trend toward having military forces perform ever more and varied functions distinct from their traditional tasks associated with territorial defense is present in

\footnotetext{
* Dr. John L. Clarke is the Director of the Program on Civil Security at the George C. Marshall European Center for Security Studies in Garmisch-Partenkirchen, Germany.
} 
every state with an army. Indeed, some countries, such as China and Egypt, have armies that are vertically and horizontally integrated into the economy, often running major business enterprises. But armies are often asked to perform more mundane tasks, such as trash collection and firefighting, often to the detriment of their readiness to carry out their primary function. For while there are benefits to the engagement of military forces in civil support tasks, there are also opportunity costs. Soldiers engaged in these tasks cannot often be rapidly redeployed. They cannot be in two places at one time, and often would require a significant amount of time to extricate themselves from a particularly challenging civil support task in order to carry out another one. Moreover, soldiers, particularly contemporary professional soldiers, are expensive, particularly when compared to conscript soldiers.

Military forces have traditionally played broad - indeed, quite expansive-roles in support of European governments, particularly when viewed from the U.S. perspective, which is characterized by legal and cultural restraints on the domestic deployment of military personnel. Military forces, particularly ground forces, have often provided key support to governments, and in more than a few cases have supplanted them. This article will review this European tradition, with a view towards establishing a basis for examining the current trends in European defense support to civil authorities, with a focus on the post-World War Two period. Tracing the development of the domestic engagement of European armed forces over three distinct phases, it will examine the range of tasks assigned to the armed forces in the domestic environment through the cultural prism of a number of European states, with special emphasis on the case of Italy.

\section{The Pre-War Tradition}

It is useful to review the role of military forces in the domestic environment in the period preceding World War Two, as it provides insights into the role of the military and how both political leaders and the senior military leadership itself have perceived it. In the period following the First World War, the armed forces of many European countries (with the notable exceptions of Germany and Great Britain) were extensively involved in domestic politics and support of political movements, when not actually constituting a political movement of their own. Soldiers and former soldiers, as well as leaders of militarized political movements (the Fascist movements in Italy and Spain come to mind) played leading, indeed dominant, roles in the politics of those countries.

This trend was evident in other European countries as well. Following the Russian Civil War, the Red Army came to play a highly significant role in support of the Communist Party in the new Soviet Union; similarly, the Austrian militias played supportive roles in the events leading up to the civil war there in February 1934. And the monarchies of the Netherlands, Belgium, Sweden, and others were highly dependent on their armed forces for maintaining domestic order during the interwar period.

Likewise, military forces in the United Kingdom were involved in extensive domestic actions, most notably their heavy involvement in Ireland, in which the British Army, along with locally recruited forces such as the Black and Tans, conducted a 
bloody counterinsurgency campaign against Irish insurgents fighting for the liberation of Ireland from British rule. ${ }^{1}$ The British Army was also involved in many other domestic contingencies, notably the bloody suppression of industrial action by trade unions in 1926, an action similar to the eviction of the Bonus Army in Washington in 1932. ${ }^{2}$ And the role of the British Army in Ireland was a textbook case of the involvement of military forces in dealing with domestic counterinsurgencies, with all the negative aspects of that involvement playing a prominent (if undesirable) role.

Even republican France saw the military play a major role during the interwar period. Military expenditures, notably for the construction of the Maginot Line, were the single largest budget item in the budgets of interwar France. And the veteran's movements, many of them organized along military lines, played prominent, indeed often dominant, roles in French politics, frequently agitating for increased spending on military projects. In Italy and Spain, Fascist governments did not hesitate to employ their armed forces in a wide range of domestic operations, many of them designed to enforce their laws and, not coincidentally, preserve the government. Only in Germany, with its demilitarized Reichswehr, did the military not play a significant domestic role during the interwar era, at least initially. But even here, militarized political movements, such as the Brown Shirts and Communists, were important actors in the German political arena.

Of course, the rise of Adolf Hitler, supported by both the Sturmabteilung (SA), the paramilitary wing of the Nazi Party, and the Schutzstaffel (SS), the party's security detail, provides an excellent example of the militarization of politics. Hitler's rise to power, and exercise of it after 1932, was militarized in the extreme. The employment of private armies, such as the SS and SA, led to a highly militarized political culture in Germany, where nearly all political figures wore uniforms and the military regained an important voice in the political affairs of the nation. This was echoed by the victory of the Blue Shirt movement under Franco in Spain and the rise of Mussolini's Fascists in Italy. The army, if not in charge of the nation, was at least one of the major players.

\section{Cold War Contributions}

With the end of World War Two and the defeat of the Axis powers, militarized politics seemed to be defeated as well. With the exception of General Franco in Spain, and later the Portuguese generals under Salazar, the role of the military in politics receded in many countries, at least in Western Europe (the role of the Soviet Army in bringing Communist governments to power in Eastern Europe is a story that is more properly

1 Michael Head and Scott Mann, Domestic Deployment of the Armed Forces: Military Powers, Law and Human Rights (Farnham, U.K.: Ashgate, 2009), 83; Jonathan Stevenson, "The Role of Armed Forces of the United Kingdom in Securing the State against Terrorism", in Armies in Homeland Security: American and European Perspectives, ed. John L. Clarke (Washington, D.C.: National Defense University Press, 2006), 23-24 and 29; and Peter Taylor, Brits: The War against the IRA (London: Bloomsbury, 2001).

2 Head and Mann, Domestic Deployment of the Armed Forces, 83. 
told elsewhere). But there was a significant interregnum: the military governments in occupied Germany and Austria.

These governments, although intended initially only as an interim solution, came to provide an intellectual basis for the appropriate role of military forces in stability operations that resounds even today. The development of a corps of Allied uniformed civilian government specialists charged with overseeing the rebuilding of those shattered economies was an innovation. The range of tasks and functions assigned to these operatives in societies that had been reduced to their bare minimum functional levels was comprehensive, ranging from the provision of essential services to the re-establishment of pre-war liberal institutions, such as a free and open media and the role of non-governmental organizations, such as Rotary Clubs. Of course, both the West German and Austrian political environment were completely demilitarized. Indeed, it took the better part of a decade to reestablish the military as a legitimate part of society in those countries. ${ }^{3}$

The role that these officers and soldiers played in the re-establishment of civil society in the heart of Western Europe is often overlooked today - but it provided prima facie evidence that armies are capable of playing an important role in this process, at least in an environment of occupation, and anticipated the developments in Iraq and Afghanistan in the past decade. Military government officers, now referred to as "civil affairs specialists," are key players in the broad range of stability and reconstruction operations that are under way around the globe.

One other aspect of military involvement in government in the immediate post-war era is worthy of comment. The role played by French military forces in suppressing the liberation movement in Algeria in the 1950s is very significant. At that time, Algeria was a part of metropolitan France - that is to say, it was considered French sovereign territory, not a colony or overseas possession. Thus, the campaign in Algeria is best regarded as a domestic counterinsurgency operation, with all its attendant challenges. The irony of France's campaign there is that, while the counterinsurgency campaign waged throughout the country and the counterterrorist campaign conducted in the major cities such as Algiers were largely successful in suppressing the insurgency, the campaign foundered on the highly negative public perception of the manner in which it was conducted and the successful internationalization of the Algerian liberation movement.

This campaign had a marked effect on the French Army in its aftermath. The high degree of politicization of the general officer corps - combined with the extremist political views of many in the Foreign Legion and other elite units of the French Army, which found their ultimate expression in the development of the Organization de L'Armée Secret (a dissident French paramilitary/terrorist organization formed in Fascist Spain and dedicated to preventing Algerian independence)—was to have long-

3 See Gerhard J. Klose, "The Weight of History: Germany's Military and Domestic Security," and Johann Frank, "A Neutral's Perspective: The Role of the Austrian Armed Forces in Homeland Security," in Armies in Homeland Security: American and European Perspectives, ed. John L. Clarke (Washington, D.C.: National Defense University Press, 2006). 
lasting and detrimental effects on the French Army and its relationship to society. Moreover, the conduct of the Algerian campaign itself, with the widespread application of torture, did the public image of the French Army no favors. ${ }^{4}$

Western European military forces, as they built up their capabilities under the aegis of NATO and in response to the growing Soviet threat, performed a number of other decidedly non-military tasks in the 1950s and 1960s. One of the more interesting and instructive was the role of the Swedish armed forces in the switch from left-hand driving to right-hand driving on Swedish roads. In 1963, Sweden decided to switch from driving on the left, as in the U.K., to the right side of the road. This was done because the great majority of automobiles in Sweden had their steering wheels on the left, as was the case with most Continental cars. Despite public opposition (nearly 83 percent of the population voted against the switch), the Swedish government ordained the change, and it was scheduled for the night of 3 September 1967. Overnight, traffic across Sweden switched sides - aided by the Swedish Army, which was mobilized to facilitate the transformation (including the reversal of traffic signs and signals). Swedish soldiers provided much of the traffic control force dedicated to this effort. ${ }^{5}$

During the Cold War, most Western European armies were fully preoccupied with their homeland defense tasks, but were frequently assigned to support law enforcement organizations, particularly in anti-terrorism efforts. In some countries, such as the U.K., this took the form of a domestic counterinsurgency campaign. Indeed, the British Army exercised primacy in Northern Ireland operations from 1970 until 1976, a period in which the police in that province were unable to assert full control. The army's experience in this operation was decidedly less than positive, and major efforts were made to finally restore police primacy by mid-decade. ${ }^{6}$

Of course, military forces in some countries in Western Europe were actively engaged in efforts to combat terrorism. Many armies developed specialized units focused on a domestic counterterrorism role, most notably the British Special Air Service, which continues to this day to play a prominent part in domestic counterterrorism operations. ${ }^{7}$ Likewise, the French Army's VIGIPIRATE operation, first launched in the early 1990s, has placed military units in support of law enforcement organizations in protecting key assets, as well as conducting counterterrorism operations in French

4 Denis Vaultier, "The Military's Role in Homeland Security in France," in Armies in Homeland Security: American and European Perspectives, ed. John L. Clarke (Washington, D.C.: National Defense University Press, 2006), 211.

5 See The Volvo Owners Club, September 3 1967: 40 years of Driving on the Right Side in Sweden (2007); available at www.volvoclub.org.uk/history/driving_on_right.shtml.

6 Head and Mann, Domestic Deployment of the Armed Forces; Stevenson, "The Role of Armed Forces of the United Kingdom in Securing the State against Terrorism"; and Taylor, Brits: The War Against the IRA.

7 See the website of the elite U.K. Special Air Service (SAS) at www.army.mod.uk/ specialforces/30603.aspx. See also Stevenson, "The Role of Armed Forces of the United Kingdom in Securing the State against Terrorism," 28. 


\section{THE QUARTERLY JOURNAL}

overseas territories. ${ }^{8}$ The Italian military also conducted numerous such operations, particularly against the Red Brigades in the 1970s and 80 s. $^{9}$

In addition to numerous antiterrorism operations conducted during this period, many European armies were frequently employed in humanitarian assistance and disaster relief (HA/DR) operations across a broad spectrum of responses to both natural and man-made disasters. The operations of the German and Austrian armed forces in response to floods on the Rhine, Oder, and Danube Rivers represent but a few of these operations. ${ }^{10}$ The Italian Army's response to a chemical plant disaster in 1976 in Seveso, north of Milan, and a landslide above the Vajont Dam in 1963 are also representative. ${ }^{11}$ Other examples would include fighting forest fires in France and Greece, as well as maritime responses to oil spills in France and Spain. ${ }^{12}$

In the context of this article concerning the European tradition of military operations in domestic contingencies during the Cold War era it is worth citing the Warsaw Pact experience as well. Though markedly different, the prominent role enjoyed by the military and security services of many Eastern European states resulted in highly militarized societies with numerous paramilitary organizations, such as the Kampfgruppen der Arbeiterklasse in the former East Germany. These organizations existed to supplement the regular military forces in these states and also served to reinforce the state security apparatus. The role of the military forces in crushing uprisings against Communist rule in Hungary in 1956 and Czechoslovakia in 1968, as well as the imposition of martial law in Poland in 1980-81, offers object lessons with regard to the dangers posed by the military playing an overwhelming role in domestic politics.

8 Statement by Jean-Pierre Raffarin, Prime Minister of France, "Présentation du nouveau plan gouvernemental de vigilance, de prevention et de protection face aux menaces d'actions terroristes: Vigipirate," (26 March 2003), Service d'information du Gouvernment; available at www.vaucluse.gouv.fr/IMG/pdf/plan_vigipirate-2.pdf. See also Denis Vaultier, "The Military's Role in Homeland Security in France," 206-7, 213, 216, 219, 226.

9 See Carlo Cabigiosu, "The Role of Italy's Military in Supporting the Civil Authorities," in Armies in Homeland Security: American and European Perspectives, ed. John L. Clarke (Washington, D.C.: National Defense University Press, 2006).

10 The military provided assistance during the flooding of the Rhine in 1993, of the Oder in 1997, and of the Danube in 2002, see Informationsplattform Undine, "Das Hochwasser der Oder in Sommer 1997," available at http://undine.bafg.de/servlet/is/15719/; and "Das Weihnachtshochwasser des Rheins 1993," available at http://undine.bafg.de/servlet/is/ 19295/. See also City of Vienna, "Hochwasser 2002," available at www.wien-vienna.at/ geschichte.php?ID=829.

11 Cabigiosu, "The Role of Italy's Military in Supporting the Civil Authorities," 95.

12 European Commission Directorate-General Joint Research Center, Institute for Environment and Sustainability Land Management Unit and Directorate-General Environment Forests Unit, "Forest Fires in Europe. 2003 fire campaign," European Communities Report 4 (Rome: European Communities, 2004); Secrétariat d'état aux transports \& à la mer: Inspection générale des services des affaires maritimes - Bureau enquêtes et accidents, Perte totale suite à avarie de coque du pétrolier bahaméen Prestige survenue dans l'ouest de la Galice. 13-19 Novembre 2002 - Contribution provisouire au rapport d'enquête technique (Paris: Secrétariat d'état aux transports \& à la mer, 2003). 


\section{Post-Cold War Tasks for Soldiers}

With the fall of the Soviet Union and the end of the Cold War, followed by the emancipation of the states of Eastern Europe, the military forces in Europe, both East and West, began a process of retrenchment as states took advantage of this interregnum to cash in on the so-called "peace dividend." This resulted in major declines in the numbers and kinds of military forces that were available not only for national defense but also for service in domestic contingencies. This coincided with an apparent rise in the numbers and kinds of contingencies that required military participation. Floods, earthquakes, and other natural catastrophes seem to have increased in both their frequency and their intensity over the past twenty years, necessitating an enhanced response. Since this has also coincided with a decline in resources available to response efforts, much of that burden has fallen on eviscerated military forces.

Natural disasters, such as floods in the United Kingdom, earthquakes in Italy, major windstorms in France, and bird flu in Germany are representative of this trend. ${ }^{13}$ But an even greater impetus for the domestic engagement of military forces has been the response to the terrorist attacks of 11 September 2001 in New York City and Washington, D.C., and the subsequent attacks in London, Madrid, and elsewhere in Europe over the ensuing decade.

The perceived necessity to provide increased levels of security, often within a constrained budget environment, has led to increased reliance on military forces to provide significant, if not major, elements of that response. In many European countries, soldiers can be seen guarding critical infrastructure, government buildings, and key tourist sites, often in full combat uniform and armed with assault rifles. The presence of French soldiers at the Eiffel Tower in Paris, or Italian soldiers guarding diplomatic missions in Rome, are emblematic of this increased military response to terrorism. The passage of enabling legislation (such as the Civil Contingencies Act of 2004 in the U.K.) has also made it easier, and thus more convenient, for political leaders to call upon military forces in response to the need for increased domestic security.

The European tradition of engaging military forces-including active, reserve, and paramilitary organizations - in domestic contingencies is well established. While there are notable exceptions, including Germany (and, to a lesser extent, Austria), many European states exhibit considerably less reluctance than in the past to call upon military forces to carry out a broad and, it would seem, increasing range of operations on their home soil. The next section of this article will analyze one such country, Italy, in

13 John Hammond, "Floods 'to become more frequent'," BBC News (19 August 2004); Paul Lewis, "Background: Italy and earthquakes. With geological faults running up its spine, Italy is prone to earthquakes - although rarely as destructive as in Abruzzo today," The Guardian (6 April 2009); Lizzy Davies, "Fatal storm sweeps through France. At least 40 killed as hurricane-force winds and torrential rains bring flooding to central and western France," The Guardian (28 February 2010); "German Military Joins Fight Against Bird Flu," Deutsche Welle (18 February 2006), available at www.dw.de/german-military-joins-fight-against-birdflu/a-1908444. 
detail, as it may be seen as a harbinger of the type of domestic demands that will be placed on military forces in the future. The balance of this article will examine what those demands are likely to be.

\section{Italy: A Case Study of Armies in Civil Security}

European civilian leaders are increasingly looking to their military forces to provide an ever-increasing range of services in the domestic arena. But this trend is not new. As noted in the previous section, European states have a rich history of employing military forces in domestic contingencies. This section will focus in particular on Italy, which has been unusually creative in its approach to having soldiers do the job - whatever the job is. Of course, each country in Europe has a different tradition in this regard. They have different national security organizations and strategies, and they have different perceptions of the threats and challenges to their domestic security. Each nation approaches these challenges in a different manner reflecting their unique histories and the status of the armed forces in their respective states. In this regard, Italy can be especially instructive, given the rich tradition, unique legal structure, and exceptionally diverse engagement of Italian military forces within Italy.

Italy has a long history of engaging its military forces in domestic contingencies. The relative ease with which successive Italian governments have turned to the military to carry out safety and security tasks makes Italy an ideal case study for determining the extent to which European governments may see military forces as acceptable substitutes for properly constituted domestic security forces. Italian governments have not hesitated to use soldiers to carry out domestic security tasks and, in some cases, to endow those soldiers with special police functions and powers.

Italian armed forces have participated in a broad range of civil support operations since the end of World War II, ranging from protecting key facilities and critical infrastructure to providing relief in response to natural disasters. Since 1992, but particularly since 2001, the Italian armed forces' role has expanded significantly, to the extent that the Italian military now undertakes a greater range of domestic security tasks than that of any other European country.

Italy does not use the homeland security concept per se, but rather employs a concept known as "presence and surveillance." This concept has three operational domains: territorial defense, disaster relief, and territorial control. The first two of these correspond to the U.S. concept of Homeland Defense and Civil Support, but the third, territorial control, has no exact equivalent in the U.S. Many of the Italian military's post-war domestic operations have been conducted under this rubric, which envisions Italian military forces conducting law enforcement-like activities. ${ }^{14}$

Italian law views the military as a full partner in many kinds of domestic contingencies. Under the law that established the Agency for Civilian Protection (225/92), the armed forces are designated as the "operational branch" of the national civil protection service. While this organization is primarily concerned with coordinating Italy's re-

14 Cabigiosu, "The Role of Italy's Military in Supporting the Civil Authorities," 113-15. 
sponse to disasters, it has become increasingly involved in working with security organizations to enhance public security. ${ }^{15}$

This history includes the stationing of thousands of Italian soldiers in the South Tirol in the 1960s in response to a separatist terror campaign designed to restore the South Tirol to Austria. ${ }^{16}$ These soldiers carried out missions to protect critical infrastructure such as power lines, as well as helping to seal the border with Austria to prevent cross-border infiltration. Soldiers performed similar functions in the 1970s throughout Italy to secure facilities such as rail infrastructure against possible attacks by the Red Brigade terrorist group.

Likewise, Italian Army units have been very active in disaster relief operations in earthquake-prone regions of Italy, most notably in the Vajont Dam disaster in 1963, in which over 3000 people died in the wake of a landslide into the Vajont reservoir, and the earthquake in Friuli in 1976, which killed a thousand and left over 150,000 homeless. ${ }^{17}$

In 1992, acting in response to the murders of two Italian prosecutors fighting the Mafia in Sicily, the Italian government decided to reinforce the law enforcement presence in the region by deploying nearly 10,000 soldiers to Sicily in an operation called Vespri Siciliani (or "Sicilian Vespers," evoking the Verdi opera of the same name). This operation employed soldiers to conduct territorial control operations throughout Sicily, including surveillance operations, patrols, checkpoints, and infrastructure security operations. The operation concluded in 1998. Over the six years of the initiative, the Italian Army checked nearly a million persons and 665,000 vehicles, and arrested 1225 persons. During this time, all nineteen brigades of the Italian Army were deployed to Sicily on a sixty-day rotational cycle. The average strength of the army in Sicily during this operation was about $6000 .^{18}$

Of significant importance was that, for this operation, soldiers were designated by an act of parliament as "public security agents," which entrusted them with law enforcement powers, including the authority to detain and arrest suspected persons. This enabled army units to act independently of police and Carabinieri units. At the same time, soldiers required significant training in order to carry out police functions, particularly with regard to the use of force. Italian law sets forth three categories for law enforcement agents: full police authority, public security agency, and a "reduced" public security function. Soldiers employed in the Vespri Siciliani operation enjoyed public security agency authority. ${ }^{19}$

15 Presidenza del Consigli dei Ministri Dipartimento della Protezione Civile, "The Italian Civil Protection National Service" (Rome: Department of Civil Protection); available at www.protezionecivile.gov.it/cms/attach/brochuredpc_eng2.pdf.

16 Cabigiosu, "The Role of Italy's Military in Supporting the Civil Authorities," 95.

17 Ibid., 95-96.

18 Ibid., 99; Head and Mann, Domestic Deployment of the Armed Forces, 106.

19 Italian Ministry of Defense, "Operation 'Vespri Siciliani'," at www.esercito.difesa.it/enUS/Activity/Operationsonthenationalterritory/Pages/OperationVespriSiciliani.aspx. 
Also in 1992, the Italian government commenced Operation Forza Paris, a similar operation of lesser scale in Sardinia, where Italian Army units conducted operations in the rugged central portion of the island. This operation, which lasted about two months and involved up to 5000 soldiers, was designed to demonstrate the government's will to maintain control over its territory, particularly difficult to reach areas that might today be called "ungoverned spaces." It was also designed to reduce the freedom of action of local criminal groups. ${ }^{20}$

During Forza Paris, Italian Army units conducted military training operations in the central portion of the island, including live-fire training and forced marches. Unlike units deployed in Sicily, these troops did not have special police powers. Rather, these operations were designed to demonstrate "presence" and thus discourage criminal activity. In addition to combat training, military engineers carried out a number of operations, such as road repair and water purification efforts. ${ }^{21}$

Later in the decade, as the violence in the Balkan region continued to increase, Italian military units were pressed into service in support of the Guardia di Finanza's mission of securing Italy's external borders. These efforts included Operation Testuggine, an army operation to control illegal immigration along Italy's land border with Slovenia, and Operation Salento, a similar effort to control illegal maritime immigration along Italy's southeast coast. Testuggine involved an average presence of 4000 soldiers, while Salento averaged 650 soldiers. Both operations involved endowing soldiers with limited police powers, which enabled them to stop and arrest suspects. ${ }^{22}$

With the end of the decade, and the advent of the War on Terror era brought on by the attacks of September 2001, the range of tasks given to the military continued to grow. In October 2001, the Italian Army commenced Operation Domino. This operation, involving up to 4000 soldiers, was designed to provide protection for 150 installations considered to be critical elements of the nation's infrastructure and thus possible targets of terrorist attack, a list which included airports, railways stations, water treatment plants, power generation facilities, and telecommunications sites. It also included increased security for foreign (mainly U.S.) military bases in Italy. In contrast with other operations, the military did not possess special police powers, and thus could not, on their own, stop and arrest suspects. Rather, they were required to have police officers (either state or Carabinieri) accompany army patrols in order to do this. The operational tempo of Domino was reduced after 2006, but some facilities still enjoy enhanced protection. ${ }^{23}$

In the latter part of the decade, the tempo and scope of domestic military involvement in Italy increased again. In addition to a number of operations designed to support police operations (such as the assignment of 2500 military personnel to carry out general security tasks and to provide emergency medical capabilities at the 2006 Turin

\footnotetext{
${ }^{20}$ Cabigiosu, "The Role of Italy's Military in Supporting the Civil Authorities," 99.

21 Ibid.

${ }^{22}$ Ibid., 99, 113-14.

23 Ibid., 100-1.
} 
Winter Olympic games, as well as to provide external security for the 2009 G8 meeting in L'Aquila), Italian military units have been assigned an ever-widening set of tasks.

In response to a perception that the overall security situation in major Italian cities had deteriorated, the Berlusconi regime once again turned to the military, this time to provide enhanced security in Italy's urban streets. Operation Strade Sicure ("Secure Streets") commenced in May 2008 by executive decree, later authorized by law number 125 of 24 July 2008. This operation was designed to support police and Carabinieri units by increasing the presence of security forces on Italian streets. Specific tasks include ensuring the external security of immigration centers in sixteen provinces (involving about 1000 soldiers); securing fifty-two sensitive locations in Rome, Milan, and Naples, mostly embassies and consulates (involving 750 soldiers); and joint police-army patrols in nine cities (involving 1500 soldiers), as well as a command and control and logistics element of about 300 soldiers. $^{24}$

Like previous operations, these soldiers have some law enforcement powers, limited to stopping and searching suspicious individuals. Such individuals must be immediately turned over to law enforcement authorities, hence the joint patrols with police/ Carabinieri officers. These joint patrols are carried out in high-traffic areas, such as bus and train stations, as well as in major tourist areas (for example, the Forum in Rome). In the first year of operation, it resulted in searches of nearly 300,000 people and 150,000 vehicles.

The second major operation launched in 2009 was Operation Strada Pulite ("Clean Streets"). Italy has a long history of organized labor action, including the refusal of sanitation workers to remove garbage. In response to the growing mountains of refuse in the streets of Campania province (Naples), Prime Minster Silvio Berlusconi authorized the province to call upon the armed forces to remove the waste material. This authority was later reinforced by Law $125 / 09$, which identified waste treatment sites as "areas of national strategic interest." This law called for an end to this status at the end of 2009 , though it was subsequently extended. ${ }^{25}$

Of note is that this operation not only included efforts undertaken to relocate the refuse to waste storage and treatment sites, but also to guarantee the security of those same sites. This is because there was much local political resistance to the establishment of these sites in the area surrounding Naples, and thus it became necessary to "guard the garbage." Another aspect of the effort was the necessity to inspect the waste material for contaminated materials, particularly radioactive materials. The operation has involved an average of 700 soldiers on a daily basis, and resulted in the removal of nearly 40,000 tons of refuse, as well as the inspection of over 110,000 trucks. $^{26}$

24 Italian Ministry of Defense, "Operation 'Strade Sicure'," available at www.difesa.it/EN/ Operations/NationalOperation/Pagine/OperationStradeSicure.aspx.

25 Matilde Maisto, “Operazione 'Strade Pulite': Cambio al Comando fra Ufficiali della Garibaldi. Cuofano Lascia il Posto a Mirra," Cancello ed Amone News (16 February 2010); Italian Ministry of Defense, "Operation 'Strate Pulite'."

26 Maisto, "Operazione 'Strade Pulite'.” 
One last recent operation deserves mention. On 6 April 2009, a major earthquake struck the Abruzzi region near the city of L'Aquila, resulting in 300 deaths and 1500 injured, as well as vast damage to property. This earthquake created an urgent need for disaster relief operations. The armed forces deployed over 1300 troops as well as large numbers of vehicles and helicopters to the region to assist in this effort in direct support of the Civil Protection Agency. ${ }^{27}$

The Italian public's reaction to most of these operations has been uniformly positive. The population has generally concurred with the decision to deploy soldiers to carry out these non-military tasks; indeed, on occasion, there have been demonstrations in favor of more military involvement, as the armed forces are now seen in Italy as an organization that "gets things done." Of course, the political benefit to those leaders responsible for ordering the military to undertake these tasks does not go unnoticed. Perhaps surprisingly, the military also takes a very favorable view of these operations. While many senior officers recognize the opportunity cost involved in deploying soldiers on these missions, they often voice support for them. This can be attributed to a number of factors.

First, these operations are believed to enhance the image of the military in Italy, where the armed forces have historically not generally been viewed as highly competent. As in many countries, the armed forces are often perceived as inactive, since the general public does not view training activities as "real" work. Frequently, the military is thought to be sitting in their barracks, waiting for something to do. This perception is often reinforced by the soldiers themselves when they are asked to recount how they spend their time. As a consequence, the public fails to appreciate the importance of force readiness, and comes to value the military only when they visibly carry out operations. This is particularly true in Italy, which long had a conscript military and which has many other security organizations (police, Carabinieri, Guardia Di Finanza, etc.) with which the military must compete for public approval and funding.

Second, the senior military leadership views these operations as a form of training. For example, the deployments to Sicily and Sardinia in the early 1990 s represented the first time the Italian military really had to deploy ground forces in this part of Italy; up to that point, the army had been principally concentrated in the northeastern corner of Italy. The Italian military learned a great deal about deployments, which was put to good use when Italy deployed forces to the Balkans in the mid-1990s.

Third, as many of these operations resembled in some manner the stability and reconstruction operations carried out as part of the many peace operations in which the Italian armed forces have participated around the world, leaders have come to view these operations as an excellent method of preparing for these deployments. In particular, they note the ability to operate in urban terrain and the close contact with civilian populations as having very close parallels with stability operations, as well as increased skills in patrolling and conducting checkpoint operations.

27 "Powerful Italian quake kills many," $B B C$ News (6 April 2009); "Italy scientists on trial over L'Aquila earthquake," BBC News (20 September 2011). 
Finally, senior leaders acknowledge that, in a constrained budget environment, these operations can provide a useful source of funding, which can be used to train personnel and units for other operations. The Italian military lacks sufficient funding to carry out training exercises for its full range of tasks. By participating in these domestic operations, the military can procure additional funding that may be used for this purpose.

Thus, it is no surprise that both the public and the government take a favorable view of these operations. It is therefore reasonable to anticipate that the government will continue to look to the military to provide a growing range of support to law enforcement, as well as engage in civil support operations of increased scope, including the possibility of providing essential services, such as water purification or trash removal. But it is also reasonable to ask if these operations are best carried out by the military, or whether it would be more efficient to further develop the capabilities of other organizations, such as the Carabinieri, to conduct them. ${ }^{28}$

In this regard, it should be noted that there are increasing tensions between the Carabinieri and the other branches of the Italian armed forces, particularly the army. Over the past few years the Carabinieri-Italy's military police force - has grown in size to a point where it challenges the army, and competes with the other armed forces for resources. Italian military leaders are quick to stress the legal status of the Carabinieri as part of the Italian armed forces, but increasingly the Carabinieri has acted in an independent manner, preferring to emphasize its ties to the Ministry of the Interior.

The array of tasks that political leaders feel comfortable having soldiers perform continues to grow in both scope and number. Particularly in states with largely conscript forces, the temptation is great to engage those soldiers in civil security tasks. While many of those tasks are indeed appropriate for military forces to perform, some simply are not. The Italian example provides us with an unusually rich history of these tasks, and presents some salient lessons for security planners who may be thinking, "Why not have the army do it?" If the Italian experience is any guide, political leaders will become increasingly creative in formulating requests for the military to do just that.

\section{Conclusion}

Does Europe need soldiers? To what end? These questions are likely to come into sharper focus as the twin dynamics of a lack of an external threat and increased budgetary pressures take hold. For, strategically speaking, Europe is at a crossroads. Few, if any, members of the European Union or NATO are confronted by an external military threat; hence the need to maintain large (or even small) standing armies has declined. Similarly, the likelihood that European nations will deploy large numbers of soldiers overseas in operations similar to those conducted over the last two decades in places

28 Italian Ministry of Defense, "Carabinieri," available at http://www.carabinieri.it/Internet/ Multilingua/EN. 
such as Kosovo, Bosnia, Iraq, and Afghanistan is also likely to decline, if only due to a lack of wherewithal, if not a lack of will. Does Europe need armies? If so, what should they do?

The trends governing European responses to these dynamics are quickening, and disturbing. European nations have already reduced their active and reserve military forces far more than is generally appreciated, and have failed to invest in newer capabilities and technologies to the extent necessary to maintain effective armed forces. Many European states have decreased their forces to the point where they are no longer capable of mounting a credible defense of their territory. And reserve forces, once the pivot of a mobilization strategy, have nearly disappeared. But given the realities of threats and budgets, how could this be otherwise?

If, as has been posited in this article, civil leaders will find ever more tasks for their armed forces, and the leaders of those forces continue to agree to take on these tasks, and even suggest some on their own, a state may find itself in the position of having a very expensive, improperly equipped, and overqualified emergency response instrument instead of a functional military force. The interests of senior military leaders in preserving the end strength of their forces may compel them to agree to such requests for domestic assistance more often. As the dynamics of the current era of fiscal difficulties proceed, they will find it ever more difficult to decline. Yet, at some point, they must find the courage to do so, lest their armies turn into public works entities. Armies, as robust as they often are, can be fragile things if they are not used in the way they were designed. Their great flexibility ought not to be used as an instrument of their own destruction. European nations' tradition of engaging soldiers in these tasks is instructive not only because it delineates what can be done, but also because it helps leaders decide what ought not be a soldier's job. 


\section{Bibliography}

Cabigiosu, Carlo. "The Role of Italy's Military in Supporting the Civil Authorities." Connections: The Quarterly Journal 4, no. 3 (2005): 59-82.

Frank, Johann. "A Neutral's Perspective: The Role of the Austrian Armed Forces in Homeland Security." In Armies in Homeland Security: American and European Perspectives, ed. John L. Clarke. Washington, D.C.: National Defense University Press, 2006.

Head, Michael, and Scott Mann. Domestic Deployment of the Armed Forces: Military Powers, Law and Human Rights. Farnham, U.K.: Ashgate, 2009.

Klose, Col. Gerhard J.. "The Weight of History: Germany's Military and Domestic Security." Connections: The Quarterly Journal 4, no. 3 (2005): 37-57.

Stevenson, Jonathan. "The Role of Armed Forces of the United Kingdom in Securing the State against Terrorism." In Armies in Homeland Security: American and European Perspectives, ed. John L. Clarke. Washington, D.C.: National Defense University Press, 2006.

Taylor, Peter. Brits: The War against the IRA. London: Bloomsbury, 2001.

Vaultier, Denis. "The Military's Role in Homeland Security in France." In Armies in Homeland Security: American and European Perspectives, ed. John L. Clarke, 211. Washington, D.C.: National Defense University Press, 2006. 